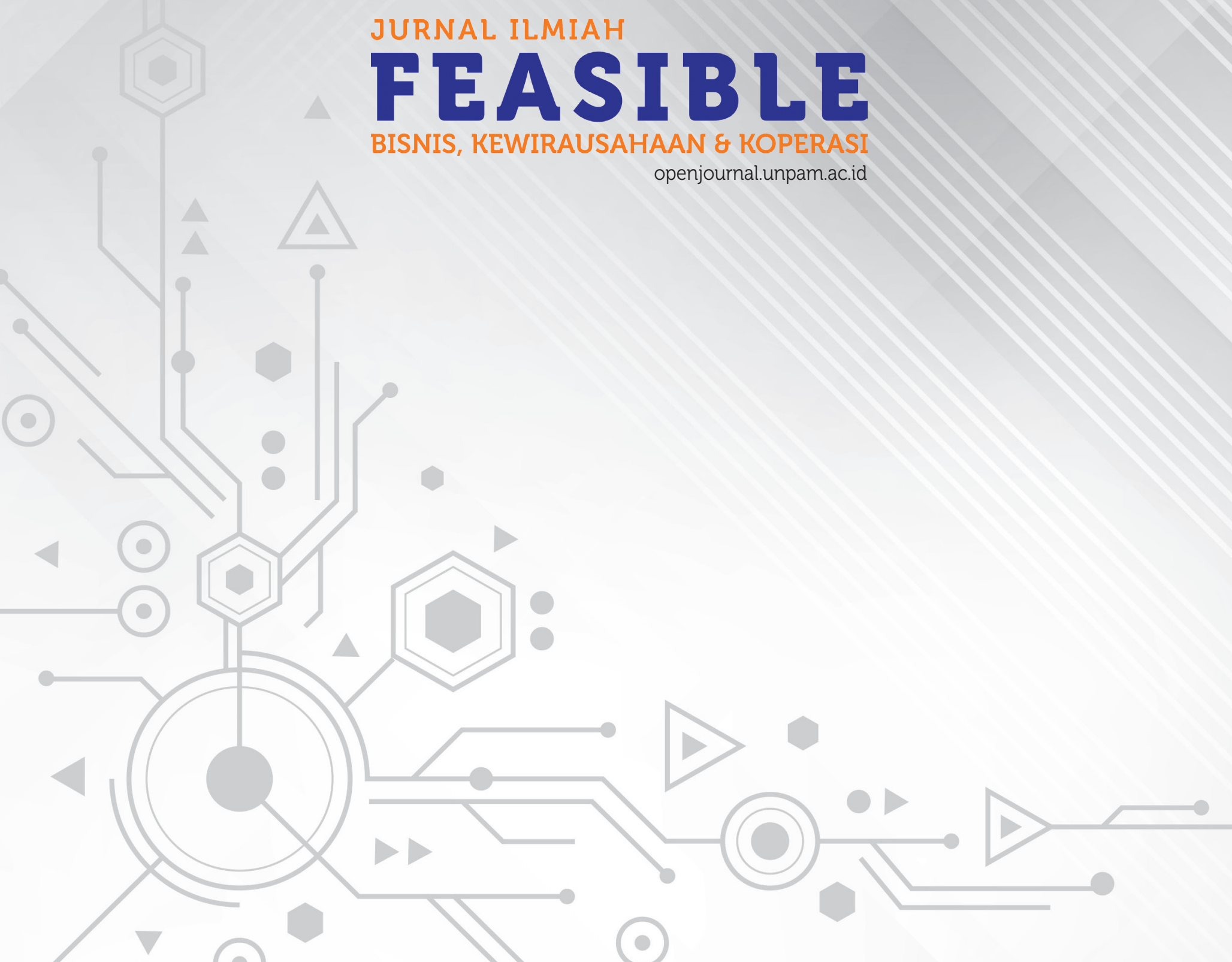




\title{
PENGARUH KUALITAS PELAYANAN TERHADAP KEPUASAN NASABAH (PADA PT. BANK SYARIAH MANDIRI CABANG PONDOK PINANG)
}

\author{
Novia Susanti.,SE.,M.M \& Arsyad Syahrian \\ Fakultas Ekonomi, Universitas Pamulang \\ Doseno0768@unpam.ac.id
}

\begin{abstract}
Abstrak
Penelitian ini bertujuan untuk mengetahui pengaruh kualitas pelayanan terhadap kepuasan nasabah PT. Bank Syariah Mandiri cabang Pondok Pinang. Metode yang digunakan bersifat deskriptif dengan pendekatan kuantitatif.Jumlah populasi sebanyak 3207 nasabah dengan sampel sebanyak 97 nasbah menggunakan sampel slovin. Teknik analisis data yang digunakan meliputi Uji Validitas, Reliabilitas, Uji Linier Regresi Sederhana, Uji Signifikan (t), serta koefisien determinasi $\left(R^{2}\right)$ menggunakan program IBM SPSS Statistik Versi 24. Hasil penelitian ini diperoleh persamaan regresi linier $Y=0,622+0,896 X$ yang berarti setiap perubahan nilai variabel kualitas pelayanan akan diikuti oleh perubahan variabel kepuasan nasabah sebesar o,896. Sedangkan nilai Adjusted $R$ Square sebesar o,995 menunjukkan 99,5\% kepuasan nasabah dapat dijelaskan oleh variabel kualitas pelayanan dan sisanya 0,5\% dijelaskan oleh variabel yang tidak diteliti. Nilai korelasi sebesar 0,997 menandakan hubungan yang sangat kuat. Hasil uji signifikasi diperoleh nilai probabilitas $0,005<$ 0,05 artiny $H_{o}$ ditolak dan $H_{a}$ diterima, sehingga diperoleh kesimpulan kualitas pelayanan memiliki pengaruh yang postif dan signifikan terhadap kepuasan nasabah pada PT. Bank Syariah Mandiri Cabang Pondok Pinang.
\end{abstract}

Kata Kunci : Kualitas Pelayanan, Kepuasan Nasabah

\begin{abstract}
This study aims to determine the effect of service quality on customer satisfaction of PT. Bank Syariah Mandiri branch of Pondok Pinang. The method used is descriptive with a quantitative approach. The total population of 3207 customers with a sample of 97 people using slovin samples. Data analysis techniques used include Test Validity, Reliability, Simple Regression Linear Test, Significant Test (t), and coefficient of determination $\left(R^{2}\right)$ using IBM SPSS Statistics Version 24 program. The results of this study obtained a linear regression equation $Y=0.622+0.896 X$ which means that each change in the value of the variable quality of service will be followed by a change in the variable customer satisfaction of 0.896 . While the Adjusted $R$ Square value of 0.995 shows that $99.5 \%$ customer satisfaction can be explained by service quality variables and the remaining $0.5 \%$ is explained by variables not examined. The correlation value of 0.997 indicates a very strong relationship. The significance test results obtained a probability value of $0.005<0.05$ means that $H_{o}$ is rejected and $H_{a}$ is accepted, so that the conclusion of service quality has a positive and significant effect on customer satisfaction at PT. Bank Syariah Mandiri Branch Pondok Pinang.
\end{abstract}

Keywords: Service Quality, Customer Satisfaction

\section{PENDAHULUAN}

\section{Latar Belakang Penelitian}

Berdasarkan data berikut bahwa adanya fluktuasi jumlah nasabah, keluhan nasabah dan dapat diidentifikasikan bahwa terjadi keluhan nasabah sebanyak $0,75 \%$ pada bulan Juni, ini berarti menandakan banyak nasabah yang kurang puas atas pelayanan dapat dilihat 
banyaknya keluhan nasabah pada saat jam operasional dan beberapa jaringan kantor yang tutup. Berikut data jaringan kantor yang ditutup:

\begin{tabular}{|c|c|c|c|c|c|}
\hline \multicolumn{5}{c|}{ Tabel 1.1. Perkembangan BSM Tahun 2014-2016 } \\
\hline No & $\begin{array}{c}\text { Kinerja } \\
\text { Operasional }\end{array}$ & 2014 & 2015 & 2016 & $\begin{array}{c}\text { Pertumbuhan } \\
2016: 2015(\%)\end{array}$ \\
\hline 1 & Jaringan Kantor & 865 & 865 & 765 & (11.56) \\
\hline \multicolumn{6}{c|}{ Sumber: Annual Report BSM Tahun 2018 } \\
\hline
\end{tabular}

Dengan melihat data tabel diatas adanya penurunan di jumlah gedung (kantor cabang) hingga mencapai 11,56\% yang berarti kualitas pelayanan nasabah menurun. Hasil penelitian yang dilakukan oleh Gustina(2011), menyatakan bahwa meningkatkan jumlah perbankan syariah itu sendiri untuk dapat menampung kebutuhan masyarakat. Hasil penelitian lainnya yang dilakukan oleh Dian (2008), menyatakan bahwa "perkembangan perbankan syariah di masa yang akan datang sangat signifikan dipengaruhi oleh perkembangan infrastruktur dan hukum perbankan syariah di Indonesia”.

Hasil penelitian yang dilakukan oleh Wikan (2015), menyatakan bahwa peran perbankan syariah masih sangat kecil dibandingkan total industri keuangan secara nasional, hal ini disebabkan karena adanya beberapa kendala yang menghambat, sehingga diperlukan suatu strategi yang dapat mengurangi semaksimal mungkin kendala yang sedang dihadapi.

Berdasarkan latar belakang dan pentingnya kualitas pelayanan yang diuaraikan di atas, maka penulis dalam penelitiannya ini mengambil judul: "Pengaruh Kualitas Pelayanan Terhadap Kepuasan Nasabah Pada PT. Bank Syariah Mandiri Cabang Pondok Pinang”.

\section{Tujuan dan Manfaat Penelitian}

Tujuan penelitian adalah sebagai berikut:

1. Untuk mengetahui kualitas pelayanan pada PT. Bank Syariah Mandiri Cabang Pondok Pinang.

2. Untuk mengetahui kepuasan nasabah pada PT. Bank Syariah Mandiri Cabang Pondok Pinang.

3. Untuk mengetahui pengaruh pelayanan terhadap kepuasan nasabah pada PT. Bank Syariah Mandiri Cabang Pondok Pinang.

\section{Tinjauan Pustaka}

\section{Manajemen}

Istilah manajemen berasal dari kata to manage yang "berarti mengelola aktivitasaktivitas sekelompok orang agar mencapai sasaran yang telah ditetapkan perusahaan atau organisasi. Manajemen secara umum sering juga disebut sebagai suatu proses untuk menyelesaikan pekerjaan melalui orang lain. Definisi ini mengandung pengertian bahwa manajemen merupakan suatu ilmu dan seni yang mempelajari bagaimana cara mencapai tujuan-tujuan organisasi melalui pengaturan orang lain untuk melaksanakan berbagai pekerjaan yang diperlukan."

Seperti yang diungkapkan oleh T. Hani Handoko (2011:10), "manajemen adalah bekerja dengan orang-orang untuk menentukan, menginterprestasikan, dan mencapai tujuan-tujuan organisasi dengan pelaksanaan fungsi-fungsi perencanaan, pengorganisasian, penyusunan personalia, pengarahan, kepemimpinan dan pengawasan".

Sedangkan menurut I Komang Ardana (2012:4), "manajemen adalah ilmu dan seni mengatur proses pemanfaatan sumberdaya manusia dan sumber lainnya secara efektif dan efisien untuk mencapai tujuan tertentu". Menurut Malayu S.P Hasibuan (2014:14), "manajemen adalah fungsi yang berhubungan dengan mewujudkan hasil tertentu melalui kegiatan orang-orang”.

Berdasarkan pendapat di atas, maka dapat manajemen diartikan adalah ilmu dan seni untuk suatu proses kegiatan mengatur dan mengelola serta memadukan sumberdaya yang dimiliki organisasi dalam mencapai suatu tujuan tertentu.

Manajemen memiliki peran penting dalam menggerakan segala sumberdaya organisasi dalam mencapai tujuan secara efektif dan efisien dalam menjalankan organisasi. segala macam aktifitas yang telah direncanakan erat kaitannya dengan kepemimpinan, peranan antar pribadi, pemberi informasi dalam pengambil keputusan, sehingga proses manajemen dapat terlaksana sesuai tujuan yang diinginkan.

\section{Pemasaran}

Pemasaran merupakan kegiatan yang sangat penting bagi setiap perusahaan untuk kelangsungan perusahaannya agar mencapai tujuan yang diharapkan. Sekarang ini banyak sekali pesaing yang memiliki produk atau jasa yang sejenis, perusahaan harus bisa terus mengembangkan produk atau jasanya dengan seiringnya perkembangan zaman. Perusahaan harus melakukan berbagai inovasi agar produk atau jasanya terus diminati oleh konsumen dan harus mampu melengkapi kebutuhan para konsumen agar mereka merasa puas.

Menurut Kotler dan Keller (2012:5), "mengidentifikasi dan memenuhi kebu- 
tuhan manusia dan sosial.Salah satu definisi yang baik dan singkat dari pemasaran adalah memenuhi kebutuhan dengan cara yang menguntungkan”. Sedangkan Kotler dan Amstrong (2012:29), "pemasaran adalah proses dimana perusahaan menciptakan nilai bagi pelanggan dan membangun pelanggan yang kuat untuk menangkap nilai dari pelanggan sebagai imbalan”.

Berdasarkan pengertian di atas dapat maka disimpulkan bahwa pemasaran adalah suatu aktifitas dalam menyampaikan barang atau jasa kepada para konsumen, dimana kegiatan tersebut dapat memenuhi kebutuhan dan kepuasan konsumen.

\section{Pengertian Jasa}

Banyak ahli pemasaran jasa yang telah mendefinisikan pengertian jasa. Yang dimaksud "jasa adalah seluruh aktivitas ekonomi dengan output selain produk dalam pengertianfisik, dikonsumsidan diproduksi pada saat bersamaan, yang memberikan nilai tambah dan secara prinsip tidak berwujud bagi pembeli pertamanya. Dimana dalam setiap kegiatannya yang ditawarkan oleh satu pihak kepada pihak lainnya, yang pada dasarnya tak berwujud dan tidak mengakibatkan seseorang memiliki sesuatu " (Wahjono, 2010:11).

Kotler dan Keller (2012:378) mengemukakan "pengertian jasa (service) adalah setiap tindakan atau kinerja yang ditawarkan oleh satu pihak ke pihak lain yangsecaraprinsiptidakberwujuddantidak menyebabkan perpindahan kepemilikan apapun”. Sedangkan Lupiyoadi (2014:7) "Jasa adalah setiap tindakan atau kegiatan yang dapat ditawarkan oleh satu pihak kepada pihak lain, pada dasarnya tidak berwujud dan tidak mengakibatkan perpindahan kepemilikan apapun. Produksi jasa mungkin berkaitan dengan produk fisik atau tidak."

Selanjutnya Zethaml dan Bitner (1996) dalam Lupioyadi (2014:7) memberikan batasan tentang jasa sebagai berikut "Jasa merupakan semua aktivitas ekonomi yang hasilnya bukan berbentuk produk fisik atau konstruksi, yang umumnya dihasilkan dan dikonsumsi secara bersamaan serta memberikan nilai tambah (misalnya kenyamanan, hiburan, kesenangan, atau kesehatan) konsumen."

Dari definisi di atas dapat diketahui bahwa dalam pemasaran jasa terdapat aspek interaksi antara pihak konsumen dengan pihak pemberi jasa.

\section{Kualitas Pelayanan}

Menurut Tjiptono \& Chandra (2011:164), "konsep kualitas dianggap sebagai ukuran kesempurnaan sebuah produk atau jasa yang berdiri dari kualitas desain dan kualitas kesesuaian (conformance quality). Kualitas desain merupakan fungsi secara spesifik dari sebuah produk atau jasa, kualitas kesesuaian adalah ukuran seberapa besar tingkat kesesuaian antara sebuah produk atau jasa dengan persyaratan atau spesifikasi kualitas yang ditetapkan sebelumnya". Maka dengan itu yang dimaksud "kualitas adalah apabila beberapa faktor dapat memenuhi harapan konsumen seperti kondisi dinamis yang berhubungan dengan produk, jasa, sumberdaya manusia, proses dan lingkungan memenuhi atau melebihi harapan".

Berdasarkan definisi di atas maka disimpulkan, "kualitas adalah sebuah bentuk pengukuran terhadap suatu nilai layanan yang telah diterima oleh konsumen dan kondisi yang dinamis suatu produk atau jasa dalam memenuhi harapan pelanggan". Menurut Kotler (2012:378) yang dimaksud dengan "pelayanan adalah setiap tindakan atau kegiatan yang dapat ditawarkan oleh satu pihak kepada pihak lain, pada dasarnya tidak berwujud dan tidak mengakibatkan kepemilikan apapun". Menurut Vargo \& Lusch dalam Tjiptono (2011:3), menyatakan bahwa "layanan atau jasa merupakan proses interaksi dalam melakukan sesuatu kepada seseorang”. Sedangkan Gummeson dalam Tjiptono \& Chandra (2011:17), mengungkapan bahwa "layanan adalah hal yang dapat dipertukarkan melalui beli dan jual namun tidak dapat dirasakan secara fisik".

Dari beberapa definisi di atas dapat disimpulkan bahwa layanan adalah sebuah aktifitas atau tindakan antara pemberi dan penerima layanan yang ditawarkan oleh pihak pemberi secara tidak berwujud sehingga tidak dapat dirasakan oleh fisik. Menurut Lewis \& Booms dalam Tjiptono \& Chandra (2011:180), kualitas layanan sebagai ukuran seberapa bagus tingkat layanan yang diberikan mampu terwujud sesuai harapan pelanggan.

Menurut Parasuraman dalam Tjiptono (2011:157), terdapat faktor yang mempengaruhi kualitas sebuah layanan adalah layanan yang diharapkan dan layanan yang diterima. Jika layanan yang diterima sesuai bahkan dapat memenuhi apa yang 
diharapkan maka jasa dikatakan baik atau positif. Jika melebihi, maka kualitas pelayanan dipresepsikan sebagai kualitas ideal. Sebaliknya lebih jelek dibandingkan yang diharapkan, maka kualitas pelayanan diperesepsikan negatif atau buruk. Sedangkan menurut Tjiptono (2011:162), "kualitas jasa atau kualitas layanan (service quality) berkontribusi signifikan bagi penciptaan diferensiasi, positioning, dan strategi bersaing setiap organisasi, baik perusahaan manufaktur maupun penyedia jasa”.

Berdasarkan definisi di atas kualitas pelayanan digambarkan sebagai bentuk sikap, tetapi tidak sama dengan kepuasan, yang dihasilkan dari perbandingan antara harapan konsumen dengan kemampuan perusahaan. Kualitas pelayanan berfokus pada manfaat yang diciptakan bagi pelanggan.

\section{Kepuasan Pelanggan}

Secara umum kepuasan (satisfaction) adalah "perasaan senang atau kecewa seseorang yang timbul karena membandingkan kinerja yang dipersepsikan produk (atau hasil) terhadap ekspektasi mereka". Menurut Kotler dalam Fandy Tjiptono (2011:312), "kepuasan konsumen adalah tingkat perasaan seseorang setelah membandingkan kinerja atau hasil yang ia persepsikan dibandingkan dengan harapannya".

Menurut Tjiptono dan Chandra (2011:292), mendeskripsikan "kepuasaan sebagai perasaan menyenangkan yang dimiliki saat mendapatkan sesuatu atau ketika sesuatu yang diinginkan terjadi dan aksi terpenuhinya kebutuhan dan keinginan". Sedangkan menurut Wahjono (2010:17) apabila perusahaan dapat mempertahankan kepuasan pelanggan dari waktu ke waktu maka akan terbentuk hubungan yang baik antara perusahaan dengan pelanggan. Hal ini tentunya akan meningkatkan keuntungan perusahaan dalam jangka panjang.

\section{METEDOLOGI}

\section{Ruang Lingkup Penelitian}

1. Tempat Penelitian

Objek penelitian ini adalah PT. Bank Syariah Mandiri Cabang Pondok Pinang yang beralamat di Jalan Ciputat Raya No. 56B Pondok Pinang Jakarta Selatan.

\section{Waktu Penelitian}

Penelitian ini dilaksanakan selama enam bulan yang dimulai bulan Maret sampai bulan Agustus 2018. Penelitian dilakukan secara bertahap diawali dengan proposal, penyempurnaan materi, pembuatan instrumen, pengumpulan data primer dan sekunder, penyebaran kuesioner, pengolahan data yang telah didapat oleh penulis dan penyusunan laporan hasil skripsi.

\section{Jenis Penelitian}

Penelitian ini merupakan asosiatif, menurut Sugiyono (2014:11) menyatakan "Penelitian yang bertujuan untuk mengetahui pengaruh atau hubungan antara dua variabel atau lebih. Penelitian asosiatif mempunyai tingkatan yang lebih tinggi bila dibandingkan dengan deskriptif dan komparatif. Dengan penelitian asosiatif ini maka dapat dibangun suatu teori yang berfungsi untuk menjelaskan, meramalkan dan mengontrol suatu gejala".

\section{Populasi dan Sampel}

\section{Populasi}

Menurut Sugiyono (2014:215) menyatakan "Populasi adalah jumlah wilayah generalisasi yang terdiri atas objek atau subjek yang mempunyai kualitas dan karakteristik yang ditetapkan oleh peneliti dan kemudian ditarik kesimpulannya". Sedangkan menurut Jonathan Sarwono (2012:18) menyatakan "Populasi merupakan kesatuan yang mempunyai karakteristik yang sama dimana sampel akan kita tarik". Menurut Husen Umar (2011:137) menyatakan "Populasi adalah kumpulan elemen yang mempunyai karakteristik yang sama dan mempunyai kesempatan yang sama untuk dipilih menjadi sampel".

Dari beberapa pengertian di atas, dapat disimpulkan bahwa populasi meliputi seluruh karakteristik atau sifat yang dimiliki oleh objek atau subjek tersebut. Sehingga yang dijadikan populasi adalah nasabah yang memiliki rekening Bank Mandiri Syariah (BSM) sebanyak 3207 orang pada bulan 31 Juni 2018.

\section{Sampel}

Menurut Sugiyono (2014:215) menyatakan "Sampel adalah jumlah dan karakteristik yang dimiliki oleh populasi tersebut”. Sedangkan menurut Suharsini Arikunto (2011:131) menyatakan "Sampel adalah sebagian atau wakil populasi yang diteliti. Pengukuran sampel merupakan suatu langkah untuk menentukan besarnya sampel yang diambil dalam melaksanakan suatu penelitian. Selain itu juga diperhatikan bahwa sampel yang dipilih harus me- 
nunjukkan segala karakteristik populasi sehingga tercermin dalam sampel yang dipilih, dengan kata lain sampel harus dapat menggambarkan keadaan populasi yang sebenarnya atau mewakili”.

Untuk menghitung penentuan jumlah sampel dari populasi tertentu yang dikembangkan, maka digunakan rumus Slovin sebagai berikut:

$\mathrm{n}=\frac{N}{N\left(d^{2}\right)+1}$

Keterangan:

$\mathrm{n}$ = Ukuran sampel

$\mathrm{N}=$ Populasi

$\mathrm{d}=$ Taraf nyata atau batas kesalahan

Untuk menentukan jumlah sampel yang akan dipilih, digunakan tingkat kesalahan sebesar $10 \%$, karena dalam setiap penelitian tidak mungkin hasilnya sempurna 100\%. Makin besar tingkat kesalahan maka semakin sedikit ukuran sampel. Jumlah populasi sebagai dasar perhitungan yang akan digunakan adalah 3207 orang, dengan perhitungan sebagai berikut:

$$
\begin{aligned}
\mathbf{n} & =\frac{3207}{3207\left(0,1^{2}\right)+1} \\
& =\frac{3207}{3207(0,01)+1} \\
& =\frac{3207}{32,07+1} \\
& =\frac{3207}{33,07} \\
& =96,97 \text { atau } 97 \text { reponden }
\end{aligned}
$$

Jadi, dari anggota populasi yang diambil sebagai sampel adalah sebanyak 97 orang responden.

\section{HASILPENELITIANDANPEMBAHASAN Deskripsi data penelitian}

1. Deskripsi Data Kualitas Pelayanan.

Rata-ratajawaban responden terhadap 10 pernyataan variabel kualitas layanan diperoleh rata-rata jawaban responden 3,30 berada diantara skala 2,61-3,40. Se hingga jawaban responden keseluruhan menyatakan kualitas pelayanan sudah cukup baik. Adapun indikator tertinggi pada indikator jaminan keamanan dalam bank dengan rata-rata skor jawaban 3,44 (cukup baik). Sedangkan indikator terendah yaitu indikator perlengkapan bank serba modern dengan nilai skor terendah 2,7.

2. Deskripsi Data Kepuasan Pelanggan.

Rata-ratajawaban responden terhadap 9 pernyataan variabel kepuasan pelanggan diperoleh rata-rata jawaban responden 3,36 berada diantara skala 2,61-3,40. Sehingga jawaban responden keseluruhan menyatakan kepuasan pelanggan sudah cukup baik. Adapun indikator tertinggi pada indikator pernyataan lahan parkir yang memadai dengan rata-rata skor jawaban 3,57 (cukup baik). Sedangkan indikator terendah yaitu indikator pelayanan yang cepat dengan nilai skor terendah 2,95.

\section{Uji Validitas dan Reliabilitas Instrumen Uji Validitas Instrumen}

Uji validitas digunakan untuk mengukur kevalidan suatu instrumen dan uji realibilitas digunakan untuk mengetahui kehandalan suatu instrumen. Instrumen dikatakan valid apabila nilai korelasi product moment $\left(\mathrm{r}_{\text {tabel }}\right)$ pada taraf siginfikansi sebesar 10\% lebih besar dari nilai $\mathrm{r}_{\text {tabel }}$ sebesar 0,168 , dan instrumen

\begin{tabular}{|c|c|c|c|}
\hline \multicolumn{4}{|c|}{$\begin{array}{c}\text { Tabel 1.2. Hasil Uji Validitas Instrumen } \\
\text { Variabel Kualitas Pelayanan }\end{array}$} \\
\hline No. Instrumen & $r_{\text {hitung }}$ & $r_{\text {tabel }}$ & Keterangan \\
\hline 1 & 0.903 & 0.168 & Valid \\
\hline 2 & 0.872 & 0.168 & Valid \\
\hline 3 & 0.804 & 0.168 & Valid \\
\hline 4 & 0.791 & 0.168 & Valid \\
\hline 5 & 0.786 & 0.168 & Valid \\
\hline 6 & 0.796 & 0.168 & Valid \\
\hline 7 & 0.831 & 0.168 & Valid \\
\hline 8 & 0.807 & 0.168 & Valid \\
\hline 9 & 0.887 & 0.168 & Valid \\
\hline 10 & 0.863 & 0.168 & Valid \\
\hline \multicolumn{4}{|c|}{ Sumber: Data diolah, 2018} \\
\hline
\end{tabular}
dikatakan reliabel jika nilai $r_{c}$ dibandingkan dengan nilai Alpha Croanbach $\left(\mathrm{r}_{\text {hitung }}\right)>0,60$.

a) Uji Validitas Instrumen Variabel Kualitas Pelayanan

Dari tabel di atas, karena karena nilai $\mathrm{r}_{\text {hitumo }}$ $>\mathrm{r}_{\text {tabel }}(0,168)$, maka seluruh instrumen kualitas pelayanan dinyatakan valid. 
b) Uji Validitas Instrumen Variabel Kepuasan Nasabah

\begin{tabular}{|c|c|c|c|}
\hline \multicolumn{4}{|c|}{$\begin{array}{l}\text { Tabel 1.3. Hasil Uji Validitas Instrumen } \\
\text { Variabel Kepuasan Nasabah }\end{array}$} \\
\hline No. Instrumen & $r_{\text {hitung }}$ & $r_{\text {tabel }}$ & Keterangan \\
\hline 1 & 0.748 & 0.168 & Valid \\
\hline 2 & 0.847 & 0.168 & Valid \\
\hline 3 & 0.880 & 0.168 & Valid \\
\hline 4 & 0.863 & 0.168 & Valid \\
\hline 5 & 0.871 & 0.168 & Valid \\
\hline 6 & 0.856 & 0.168 & Valid \\
\hline 7 & 0.885 & 0.168 & Valid \\
\hline 8 & 0.871 & 0.168 & Valid \\
\hline 9 & 0.893 & 0.168 & Valid \\
\hline \multicolumn{4}{|c|}{ Sumber: Data diolah, 2018} \\
\hline
\end{tabular}

Dari tabel di atas, karena karena nilai $\mathrm{r}_{\text {hitung }}>\mathrm{r}_{\text {tabel }}(0,168)$, maka instrumen seluruh instrumen kepuasan nasabah dinyatakan valid.

c) Uji Reliabilitas Instrumen.

\begin{tabular}{|c|cc|c|}
\hline \multicolumn{4}{|c|}{ Tabel 1.4. Uji Reliabilitas } \\
\hline Variabel & \multicolumn{2}{|c|}{ Cronbach's Alpha } & N of Items \\
\hline Kualitas Pelayanan & Var.X &, 951 & 10 \\
\hline Kepuasan Nasabah & Var.Y &, 954 & 9 \\
\hline \multicolumn{3}{|c|}{ Sumber: Data Diolah } \\
\hline
\end{tabular}

Dari tabel 1.4. dapat disimpulkan bahwa nilai Crombach's Alpha kualitas pelayanan dan kepuasan nasabah lebih besar dari o,60, maka semua variabel dinyatakan reliabel.

\section{Uji Koefisien Korelasi}

Uji koefisien korelasi digunakan untuk mengetahui tingkat hubungan variabel kualitas pelayanan terhadap kepuasanan nasabah.

\begin{tabular}{|c|c|c|c|}
\hline \multicolumn{4}{|c|}{ Tabel 1.5. Hasil Uji Koefisien Korelasi } \\
\hline & & $\begin{array}{c}\text { Kualitas } \\
\text { Pelayanan }(X)\end{array}$ & $\begin{array}{c}\text { Kepuasan } \\
\text { Nasabah (Y) }\end{array}$ \\
\hline \multirow{3}{*}{ Kualita Pelayanan X } & $\begin{array}{l}\text { Pearson } \\
\text { Correlation }\end{array}$ & 1 & $.997^{* *}$ \\
\hline & Sig. (2-tailed) & & .000 \\
\hline & $\mathrm{N}$ & 97 & 97 \\
\hline \multirow{3}{*}{$\begin{array}{c}\text { Kepuasan Nasabah } \\
\text { Y }\end{array}$} & $\begin{array}{l}\text { Pearson } \\
\text { Correlation }\end{array}$ & $.997^{* *}$ & 1 \\
\hline & Sig. (2-tailed) & .000 & \\
\hline & $\mathrm{N}$ & 97 & 97 \\
\hline \multicolumn{4}{|c|}{ Sumber: Data diolah, 2018} \\
\hline
\end{tabular}

Dari analisis perhitungan di atas, diperoleh nilai koefisien korelasi $r_{x y}=0.997$, artinya tingkat hubungan antara kualitas pelayanan dengan kepuasan nasabah positif dan sangat kuat.

\section{Analisis Regresi Linier Sederhana}

Analisis regresi ini digunakan untuk mengetahui besarnya pengaruh kualitas pelayanan terhadap kepuasan nasabah.

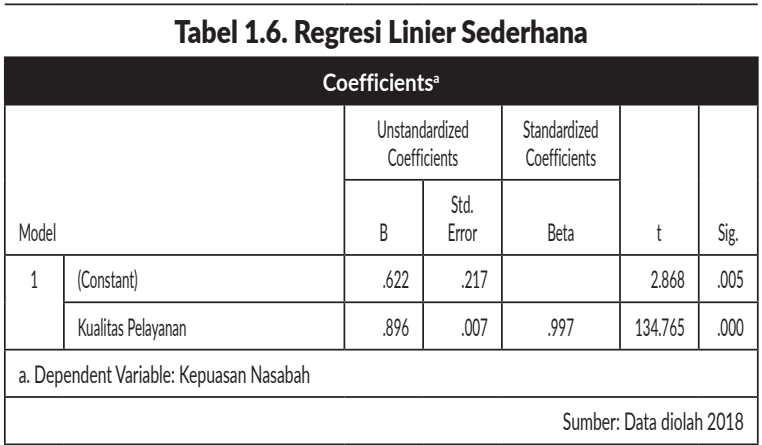

Dari tabel di atas, nilai konstanta (a) sebesar 0.622 sedang nilai koefisien regresi (b) sebesar 0.896. Sehingga persamaan regresinya diperoleh $\mathrm{Y}=0,622+0,896 \mathrm{X}$. Artinya setiap terjadi perubahan nilai variabel kualitas pelayanan akan diikuti oleh perubahan variabel kepuasan nasabah yaitu sebesar 0,896 pada konstanta 0,622.

\section{Uji Koefisien Determinasi ( $\left.\mathbf{R}^{\mathbf{2}}\right)$}

\begin{tabular}{|c|c|c|c|c|}
\hline \multicolumn{5}{c|}{ Tabel 1.7. Koefisien Determinasi ( $\left.\mathbf{R}^{2}\right)$} \\
\hline Model & $R$ & $R$ Square & Adjusted R Square & $\begin{array}{c}\text { Std. Error of the } \\
\text { Estimate }\end{array}$ \\
\hline 1 & $.997^{\mathrm{a}}$ & .995 & .995 & .398 \\
\hline
\end{tabular}

Dari tabel di atas, nilai koefisien korelasi (R) yaitu sebesar 0,997 dan nilai koefisien determinasi (R Square) sebesar 0,995 yang mengandung pengertian bahwa pengaruh variabel bebas (kualitas pelayanan) terhadap variabel terikat (kepuasan nasabah) adalah sebesar 99,5\% sedangkan sisanya 0,5\% dipengaruhi oleh faktor lainnya.

\section{Uji Signifikan (t)}

\begin{tabular}{|c|c|c|c|c|c|c|}
\hline \multicolumn{7}{|c|}{ Tabel 1.8.Hasil Uji Signifikan (t) } \\
\hline \multirow{2}{*}{\multicolumn{2}{|c|}{ Model }} & \multicolumn{2}{|c|}{$\begin{array}{l}\text { Unstandardized } \\
\text { Coefficients }\end{array}$} & \multirow{2}{*}{$\begin{array}{c}\begin{array}{c}\text { Standardized } \\
\text { Coefficients }\end{array} \\
\text { Beta }\end{array}$} & \multirow[b]{2}{*}{ t } & \multirow[b]{2}{*}{ Sig. } \\
\hline & & B & $\begin{array}{l}\text { Std. } \\
\text { Error }\end{array}$ & & & \\
\hline \multirow[t]{2}{*}{1} & (Constant) & .622 & .217 & & 2.868 & .005 \\
\hline & Kualitas Pelayanan & .896 & .007 & .997 & 134.765 & .000 \\
\hline \multicolumn{7}{|c|}{ a. Dependent Variable: Kepuasan Nasabah } \\
\hline \multicolumn{7}{|c|}{ Sumber: Data diolah 2018} \\
\hline
\end{tabular}

Dari tabel di atas dapat diketahui bahwa $t_{\text {hitung. }}$ sebesar 134.765 sehingga untuk mengetahui nilai signifikansinya, penulis akan membandingkan dengan $t_{\text {tabel }}$. Nilai $t_{\text {tabel }}$ ditentukan berdasarkan tingkat signifikan yang di- 
gunakan dan derajat kebebasan $(\mathrm{df}=\mathrm{n}-2)$ yaitu $\mathrm{df}=97-2=95$, dengan taraf nyata yang penulis gunakan sebesar 10\% (0.10), maka dapat diketahui $\mathrm{t}_{\text {tabel }}=1,290$.

Dari perhitungan diatas dapat dilihat bahwa $\mathrm{t}_{\text {hitung }}=134.765$ lebih besar dari $\mathrm{t}_{\text {tabel }}=1,290$ $\left(\mathrm{t}_{\text {hitung }}>\mathrm{t}_{\text {tabel }}\right.$ ), hal ini menunjukkan bahwa kualitas pelayanan berpengaruh signifikan terhadap kepuasan nasabah pada PT. Bank Syariah Mandiri Cabang Pondok Pinang.

\section{SIMPULAN}

\section{Kesimpulan}

Berdasarkan penelitian dan analisis data yang dilakukan dalam penelitian ini mengenai Pengaruh Kualitas pelayanan Terhadap Kepuasan Nasabah Pada PT. Bank Syariah Mandiri Cabang Pondok Pinang, maka penulis menarik kesimpulan sebagai berikut:

1. Kualitas pelayanan yang diberikan oleh PT. Bank Syariah Mandiri Cabang Pondok Pinang terhadap nasabahnya mendapat respon yang baik dengan melihat hasil jawaban responden dengan interval tertinggi 3,44 yaitu pada indikator jaminan dimana pernyataan "Jaminan keamanan dalam bank." Sehingga banyak responden yang memilih untuk menggunakan jasa perbankan PT. Bank Syariah Mandiri Cabang Pondok Pinang untuk memenuhi kebutuhannya.

2. Kepuasan nasabah masih dikategori baik dengan melihat hasil jawaban responden dengan interval tertinggi 3,57 yaitu pada indikator membeli kembali dimana pernyataan "Lahan parkir yang memadai." Sehingga banyak responden yang memilih untuk menggunakan jasa perbankan PT. Bank Syariah Mandiri Cabang Pondok Pinang, karena dengan lahan parkirnya yang cukup memadai.

3. Terdapat pengaruh yang sangat besar antara kualitas pelayanan dengan kepuasan nasabah PT. Bank Syariah Mandiri Cabang Pondok Pinang. Dapat pula diketahui besarnya pengaruh kualitas pelayanan terhadap kepuasan nasabah pada PT. Bank Syariah Mandiri Cabang Pondok Pinang yaitu sebesar 99,5\% dan sisanya sebesar 0,5\% dipengaruhi oleh faktor lain. Dan hasil pengujian signifikan, $\mathrm{t}_{\text {hitung }} 134.765>\mathrm{t}_{\text {tabel }} 1,290$ maka $\mathrm{H}_{0}$ ditolak dan $\mathrm{H}_{\text {a }}$ diterima, dengan demikian terdapat pengaruh kualitas pelayanan terhadap kepuasan nasabah pada PT. Bank Syariah Mandiri Cabang Pondok Pinang.

\section{Saran}

Berdasarkan hasil penelitian, maka penulis memiliki saran-saran terkait dengan kualitas pelayanan dengan kepuasan nasabah tujuannya agar lebih baik, yakni sebagai berikut:

1. Perusahaan harus lebih meningkatkan kualitas pelayanan dari indikator bukti fisik dimana "Perlengkapan bank serba modern." Karena diperoleh skor terendah 2,7. maka dari itu perusahaan harus meningkatkan kembali kualitas pelayanan dari segi penggunan alat yang serba modern. Walaupun sudah memiliki perlengkapan bank tetapi harus ditingkatkan lagi ke alatalat yang modern sehingga nasabah yang menggunakan jasa di PT. Bank Syariah Mandiri Cabang Pondok Pinang bisa terpenuhi keinginannya.

2. Perusahaan harus lebih memperhatikan kepuasan nasabah dari indikator bercerita keoranglaindimanapernyataan "Pelayanan yang cepat." Karena diperoleh skor terendah 2,95. Maka dari itu perusahaan harus lebih memperhatikan kembali kepuasan nasabah dan meningkatkan kecepatan karyawan dan karyawati dalam melayani nasabah. Sehingga nasabah yang menggunakan jasa di PT. Bank Syariah Mandiri Cabang Pondok Pinang bisa terpenuhi keinginannya dan terpuaskan.

\section{DAFTAR PUSTAKA}

Andi, Supangat. 2011. "Statistika Dalam Kajian Deskriptif, Infrensi dan Non Parametric". Edisi Pertama. Jakarta: Kencana Predana Media Group.

Anita, Nova., dkk. 2014. "Pengaruh Kualitas Pelayanan Terhadap Kepuasan dan Dampaknya Terhadap Loyalitas Nasabah Perbankan di Kota Langsa". Jurnal Manajemen Vol. 4, No 1, ISSN 0853-9189 page 14-32.

Ardana, I Komang, dkk. 2012. "Manajemen Sumber Daya Manusia". Yogyakarta: Graha Ilmu.

Arikunto, Suharsimi. 2011. "Prosedur Penelitian Suatu Pendekatan Praktek”. Jakarta: PT. Rineka Cipta.

Astri, Nita Nur. 2014. "Pengaruh Fee Based Income Terhadap Profitabilitas Bank Umum Swasta Nasional Devisa Yang Terdaftar Di BEI Periode 2010-2013”. S1 Thesis, Universitas Pendidikan Indonesia.

Cristie, Priskila Agatha. 2013. "Pengaruh Kualitas Pelayanan Terhadap Kepuasan Nasabah Pada BPR Syariah Rinjani Batu”. Vol 1, No 2: Semester Genap 2012/2013.

Dewi, Gusti Ayu Putu Ratih Kusuma., dkk. 2014. "Pengaruh Kualitas Pelayanan Terhadap Kepuasan dan Loyalitas Nasabah 
PT. BPR Hoki di Kabupaten Tabanan”. Jurnal Ekonomi dan Bisnis 3.5: 257-275, Universitas Udayana.

Fayol, Henry. 2010. "Manajemen Public Relation”. Jakarta. PT Elex Media.

Gustina. 2011. "Islamic Banking Sistem: Studi Analisis Perkembangan Syariah Di Indonesia". Vol 6, No 1.

Handoko, T. Hani. 2011. "Kualitas Pelayanan Publik”. Yogyakarta: BPFE.

Heria, dan Hyacintha. 2017. "Execellent Service The Secrets of Buildilng a Service Organization". Jakarta: PT. Gramedia Pustaka Utama.

Husen, Umar. 2011. "Metode Penelitian Untuk Skripsi dan Tesis Bisnis Edisi II". Jakarta: PT. Raja Grafindo Persada.

Istijianto. 2010. "Riset Sumber Daya Manusia. Edisi revisi”. Jakarta: Gramedia Pustaka Umum.

Kotler, Philip \& Kevin Lane Keller. 2012. "Marketing Management". US of America: Pearson Education.

Philip \& Amstrong, Gary. 2008. "Prinsip-Prinsip Pemasaran". Edisi kedua belas jilid satu, Penerbit Erlangga, Jakarta.

Kasmir. 2012. "Dasar-dasar Perbankan". Jakarta: PT Raja Grafindo Persada.

Lupiyoadi. Rambat. 2014. "Manajemen Pemasaran Jasa". Edisi 3. Jakarta: Salemba Empat.

Natalia, Nia \& Kamaludin, kamaludin \& Sri, Adji Prabowo. 2015. "Pengaruh Fee Based Income Terhadap Tingkat Return On Asset (ROA) Studi Pada Bank Umum Pemerintah Yang Go Publik. Masters Thesis". Universitas Bengkulu.

Nugroho, Novemy Triyandari. 2014. "Pengaruh Kualitas Pelayanan Terhadap Kepuasan dan Loyalitas Pelanggan (Survei pada Pelanggan Speddy Telkom di Kota Surakarta)". Jurnal Paradigma Vol.12, No.02.

Parasuraman, A. Valerie. 2001. "Delivering Quality Service”. The Free press, New York.

Pramita, Cempaka Dyah., dkk. 2015. "Pengaruh Servicescape (Lingkungan Layanan) Terhadap Kepuasan dan Dampaknya Pada Loyalitas Nasabah (Survei Pada Nasabah Tabungan Simpeda PT. Bank Pembangunan Jawa Timur Tbk. Kantor Cabang Kediri)”. Jurnal Administrasi Bisnis (JAB), Vol.26, No.2, Universitas Brawijaya Malang.

Putri, Resta Widya., dkk. 2015. "Pengaruh Kualitas Pelayanan Terhadap Kepuasan dan Loyalitas Pelanggan (Survey Pada Pelanggan Auto 2000 Waru Surabaya)". Jurnal Administrasi Bisnis (JAB), Vol.1,
No.1, Universitas Brawijaya Malang.

Rae, Dian Ediana. 2008. "Arah Perkembangan Hukum Perbankan Syariah”. Vol 6, No 1.

Riduwan. 2014. "Dasar-Dasar Statistika". Bandung: Alfabeta Press.

S.P, Hasibuan, Malayu. 2014. "Manajemen Sumber Daya Manusia". Edisi Revisi. Jakarta: PT. Bumi Aksara.

Sastrawinata, Hendra. 2010. "Pengaruh Kualitas Pelayanan Jasa Terahadap Kepuasan Nasabah Pada PT Bank Negara Indonesia (Persero) TBK Kantor Cabang Utama Palembang. Vol 1, No 1".

Sarwono, Jonathan. 2012. "PATH ANALiSIS Teori Aplikasi, Prosedur Analisis Untuk Riset Skripsi, Tesis dan Disertasi (Menggunakan SPSS)”. Jakarta: PT. Elex Media Komputindo.

Setiadi, pompon B. 2010. "Analisis Hubungan Spread Of Interest Rate Fee Based Income, dan Loan To Deposit Ratio Dengan ROA Pada Perbankan Di Jawa Timur: Jurnal Mitra Ekonomi dan Manajemen Bisnis. Vol 1".

Sugiarti, Ni Made \& Nuridja, I Made \& Indrayani, Luh. 2014. "Pengaruh Kualitas Pelayanan Terhadap Kepuasan Nasabah Pada PT BPR Ulatidana Rahayu Di Kecamatan Sukawati Tahun 2012. Vol 4, No 1".

Sugiyono. 2014. "Metode Penelitian Kuantitatif Kualitatif dan R\&D”. Bandung: Alfabeta.

Tauriana, Dian. 2012. "Bauran Pemasaran, Manajemen Hubungan Pelanggan dalam Menciptakan Loyalitas Konsumen”. Vol 11, No 1.

Tjiptono, Fandy. 2004. "Kepuasan dalam pelayanan". Penerbit Salemba Empat, Jakarta.

Fandy. 2009. "Service Marketing, Esensi dan Aplikasi”. Yogyakarta: Marknesis.

, Fandy. 2012. "Pemasaran jasa". Edisi pertama. Bayumedia Publishing. Malang. Fandy. 2014. "Pemasaran Jasa: Prinsip, Penerapan, Penelitian”, Yogyakarta: ANDI.

Fandy dan Chandra, Gregorius. 2011. "Service, Quality \& Satisfaction". Edisi Ketiga. Yogyakarta: ANDI.

Utami, Wikan Budi. 2015. "Perkembangan Perbankan Bagi Hasil Di Indonesia”. Vol 1, No 1.

Wahjono, Sentot Imam. 2010. "Manajemen Pemasaran Bank". Yogyakarta: Graha Ilmu.

Wibisono, Dermawan. 2006. "Manajemen Kinerja”. Erlangga Surabaya .

Zeithaml, Valerie A \& Bitner, Mary Jo. 1996. "Service Marketing". 1 edition New York : Mc Graw Hill. 